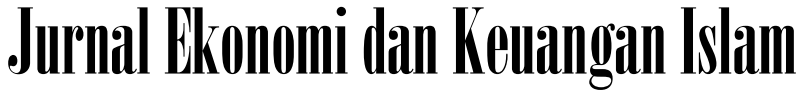

Available at https://journal.uii.ac.id/jeki

\section{Mapping the global Islamic equity market vis-à-vis the COVID-19 turbulence}

\author{
Muhamad Rizky Rizaldy ${ }^{1}$, Siti Rahayu ${ }^{2}$ \\ ${ }^{1}$ Department of Islamic Economics, Faculty of Economics, Gunadarma University, Jakarta, Indonesia \\ 2Department of Management, Faculty of Economics, Gunadarma University, Jakarta, Indonesia
}

\section{Article History}

Received : 3 June 2021

Revised : 27 June 2021

Accepted : 31 June 2021

Published : 10 July 2021

Keywords:

Islamic capital market, global Islamic equity market, asset allocation, COVID 19

DOI:

https://doi.org/10.20885/JEKI.vol7.is s2.art6

JEL Classification:

F01, F21, G11, G17

Corresponding author:

rizaldy@staff.gunadarma.ac.id

Author's email:

sitirahayu@staff.gunadarma.ac.id

Paper type

Research paper

Cite this article:

Rizaldy, M. R., \& Rahayu, S. (2021). Mapping the global Islamic equity market vis-à-vis the COVID-19 turbulence. Jurnal Ekonomi dan Keuangan Islam, 7(2), 175-188. https://doi.org/10.20885/JEKI.vol7.iss2. art6

\begin{abstract}
Purpose - COVID-19 typically affects economic activity and growth, including the movement of global Islamic stock indices. This experimental study intends to analyse and map the global Islamic equity markets competition and identify which countries had the best performance while facing the turbulence of COVID-19.

Methodology - This research was conducted by simulating the formation of a global Islamic stock portfolio and ranking based on weighting of investment allocations in each country. The data used were monthly data during the first year of the COVID-19 crisis period from 12 countries that provide an Islamic stock index and are constituents of Dow Jones Global Islamic Indices and/or FTSE Shariah. The Single Index Model was employed as the method in the formation of the global portfolio in this research.
\end{abstract}

Findings - Our analysis revealed that four countries that deserve the biggest weights, namely China, Japan, Turkey, and Malaysia, were the countries with the best relative performance compared to their risk and the most defensive countries to the global systematic market risk and turbulence during the first year of the COVID-19 crisis period. On the other hand, three countries were eliminated as their Excess Return to Beta were lower than the Cut-Off Point, these countries were the United Kingdom, United Arab Emirates, and Canada, which means that the returns of these countries were not worth the risks.

Originality - While some studies have analysed the behaviour of Islamic stock markets during the COVID-19 crisis, none of them tried to map the global Islamic stock market that reflects the competitiveness of the constituent countries and the competition amongst them.

Practical implication - This research argues that if Islamic multinational investors allocate their funds while facing the COVID19 turbulence by considering the global map generated from this study, the investors will have a global Islamic investment portfolio with an optimal return which is higher than the market return and minimal risk which is lower than the market risk.

\section{Introduction}

The COVID-19 pandemic has impinged the lives of almost the entire global community. Not limited to the health countenance, it systematically triggers crisis in all dimensions of life, including the foundations of our economy. The social restriction policies that have been forced to be adopted by most societies are apparently the main antecedent of the limited economic progress and growth. The World Bank stated that this crisis may continue to have impacts on our economic development 
for the next several decades. They predict that the global economy will shrink by $5.2 \%$ p.a. during the early years of the pandemic and consider it as the worst recession since World War II (World Bank, 2020).

Islamic economics and finance have always been able to offer something in times of crisis, as at first the Great Depression and World War II stimulated the Islamic scholars to formulate and establish what we now identify as the contemporary Islamic economics and finance, the series of crises in the last decades also made the world turn their attention to the Islamic finance due to its stability and resilience during turbulence times (Askari et al., 2010; Chapra, 2011; Faye et al., 2013; Fitriany, 2012; Jawadi et al., 2014; Rizvi et al., 2015), and the current COVID-19 crisis is no exception. There is an increasing interest in public trust in Islamic finance in this time of crisis, this can be seen from the positive movement of stock prices from issuers that are explicitly Shariabased such as shares from Islamic banks (Puspaningtyas, 2020; Sugiharto et al., 2021) that still experience positive growth in their fundamental aspects despite the crisis.

The capital market evidently supports the economic growth (Dewandaru et al., 2014; Kassim, 2016; Narayan \& Narayan, 2013; Rousseau \& Wachtel, 2000), this is expected to have an essentially similar function to the Muslim countries as many of them are still considered as underdeveloped. In a pragmatic way, Islamic capital market is aimed to draw the trust and attention from the potential Muslim investors to boost their involvement, so that the expected economic advantages could be realized and optimized. Stock movements can reflect the quality of a country's economic fundamentals (Enisan \& Olufisayo, 2009), thus, periods of turbulence can be used as the right momentum to measure the competitiveness of countries including those that have a Sharia menu in the context of global diversification. Global diversification between countries can help Islamic investors achieve optimal portfolios (Abbes \& Trichilli, 2015; Balc1lar et al., 2015; Majid \& Kassim, 2010; Saiti et al., 2014). It is very interesting to see how the competitive landscape between countries providing Islamic stock indexes relates to returns and risks during the COVID-19 pandemic crisis.

\section{Literature Review}

Various Islamic economic discourses have grown and developed rapidly in almost all countries in the world, both among academics and practitioners, both in countries with Muslim majority populations and those that are not. This also has implications for the development of the Islamic capital market which is the most important part of the Islamic financial industry in addition to its major sector, which is the Islamic banking. The Islamic capital market has broad development potential and a strategic role to be able to increase the market share of the Islamic financial industry in the world (Ali, 2007; Hearn et al., 2011; Iqbal \& Mirakhor, 2013; Najeeb \& Vejzagic, 2013).

Investment as part of a business is an activity to develop money for profit. The spirit of getting the highest possible profit at the lowest possible cost has been the main motivation in the investment, this has caused investment actors to tend to be exploitative by taking advantage of losses that befall others (Ali, 2007). The result is an investment where disharmony is both mundane and natural. This is different from the concept of Islamic investment, Islam with all its instruments is here to build a more just and more harmonious investment (Ahmed, 2003). Basically, Islam wants a balance in various aspects of life, including in the sphere of business and investment, through the application of Islamic rules extracted from Islamic legal sources. However, Islamic investment is still universal, it means that anyone, both Muslims and non-Muslims, can carry out investments in accordance with sharia (Rivai, 2010). Islamic investment does have many advantages and unique characteristics compared to conventional investment so far. Cherif and Gammoudi (2011) prove that the Islamic index in the Middle East and North Africa region is more immune to global economic shocks than the index as a whole in these countries.

The decline in world confidence in economic resilience of Europe and the United States led to a massive withdrawal of investment funds from these two giant economic regions, including investment funds originating from Middle East countries. This provides opportunities for other countries to then offer investments with sharia principles in order to attract investors from these oil-producing countries (Balc1lar et al., 2015; Saiti et al., 2014). One of the efforts to gain the trust 
of investors, especially those from the Middle East and other Muslim-majority countries, many countries have released Islamic stock indexes to facilitate the selection of stocks that comply with sharia. They provide assurance that the business sectors of listed stocks offered in the index do not violate sharia principles. Ideally the Islamic capital market does not contain ribawi (interest-based) transactions, dubious transactions (gharar), and shares of companies engaged in prohibited sectors such as alcohol and pork-based industries (Mahfooz \& Ahmed, 2014; Rizaldy \& Ahmed, 2019). The Islamic capital market must be free from unethical and immoral transactions, such as market manipulation, insider trading transactions, selling shares that are not yet owned, and buying them later (short selling) (Rethel \& Abdalloh, 2015).

According to Hakim and Rashidian (2002), after being introduced in 1999, the Dow Jones Islamic Market World Index (DJIM) has succeeded in attracting a high response from Muslim investors from all over the world. This index fulfils the needs of investors to choose stocks that comply with sharia and also serves as a benchmark in comparing the performance of their sharia stock portfolios (Binmahfouz, 2012; Maharani, 2017). In general, the activities of the Islamic capital market do not differ from conventional capital markets, however, as mentioned earlier, there are some special characteristics of the Islamic capital market, namely that the products and transaction mechanisms do not conflict with Islamic principles. The application of Islamic principles in the capital market is based on the Quran as the highest source of law and the Hadith of the Prophet Muhammad. Furthermore, from these two sources of law, the scholars made interpretations which were later called fiqh (Mahfooz \& Ahmed, 2014; Marzban \& Asutay, 2012; Mohamad et al., 2015).

There are two stages of screening in the formation of the Islamic index, namely qualitative screening and quantitative screening (Hambali et al., 2010; Khatkhatay \& and Nisar, 2007; Rahman et al., 2010). In Figure 1, we can see that qualitative screening focuses on eliminating companies that explicitly have non-halal business activities, such as companies from the conventional financial sector or pork-based goods producers, while quantitative screening focus on the certain financial ratios formulated by the Sharia board of each market. The main focus on quantitative screening is to eliminate companies deriving significant income from non-halal sources and companies that have excessive leverage in order to avoid usury and trade of debt (bai al dain) which are prohibited in Islam. Literature shows that the application of a different Shariah screening criteria will then lead to significantly different portfolios with different constituents and performance (Derigs \& Marzban, 2008; Rizaldy \& Ahmed, 2019). These generated Islamic stock indices are usually considered to have lower risk and better performance and provide diversification advantages (Abbes \& Trichilli, 2015; Ashraf, 2013; Ashraf \& Mohammad, 2014; Balc1lar et al., 2015; Fethi et al., 2014; Majid \& Kassim, 2010; Munawaroh \& Sunarsih, 2020; Saiti et al., 2014)

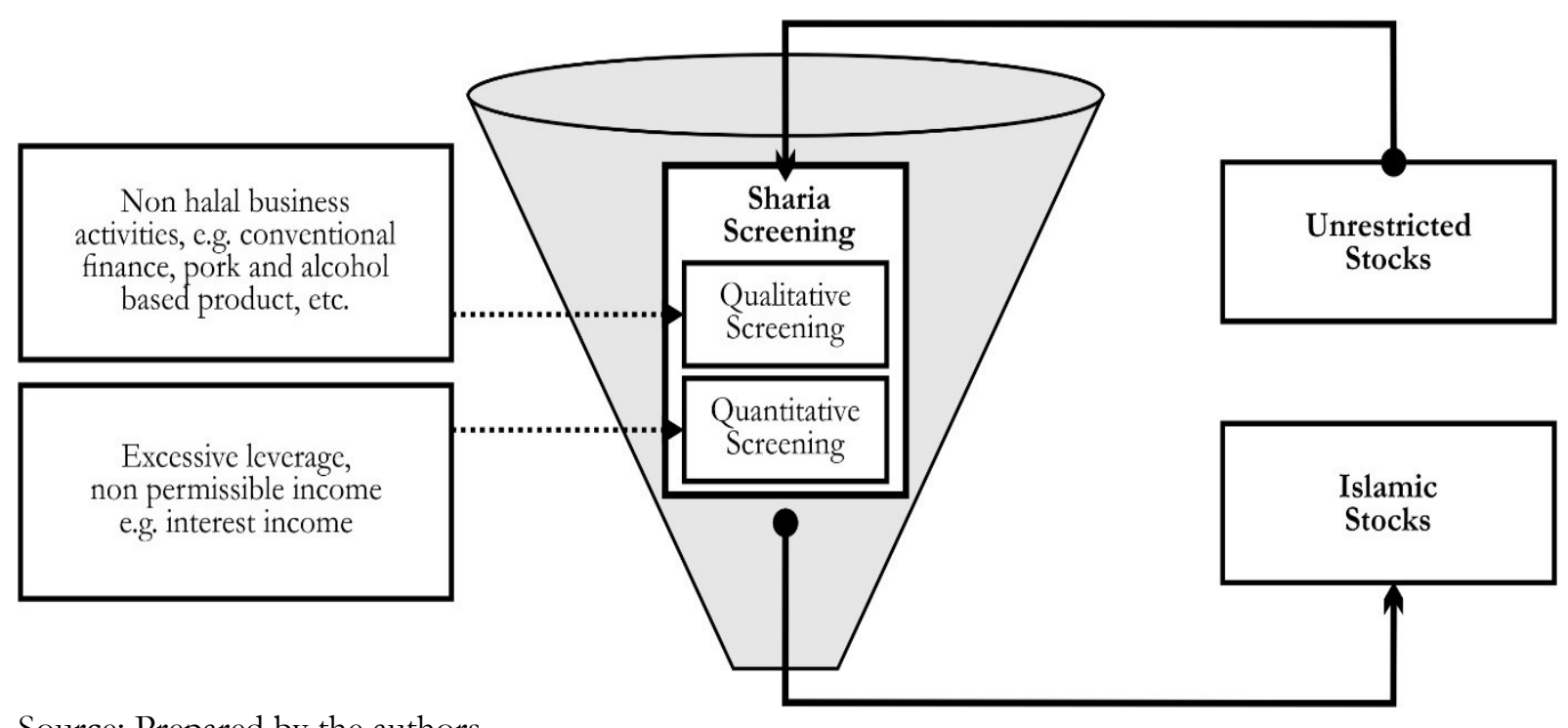

Source: Prepared by the authors

Figure 1. Sharia Stock Screening Process 
The availability of various Islamic investment options from various countries asserts global Islamic investors to be careful in making investment decisions, not only taking the halal value into account, but also the rate of return and the level of risk. One of the efforts that can be made by investors to optimize returns and minimize risk is to diversify their investments in several countries at once by building an optimal global Islamic investment portfolio using the Single Index Model (Alteza, 2010). Bodie et al. (2006) stated that in the formation of a portfolio, investors always want to maximize the expected return with a certain level of risk that they are willing to bear or look for a portfolio that offers the lowest risk with a certain level of return. This characteristic of a portfolio is referred to as an efficient portfolio.

In the context of portfolio management, the greater the number of constituents included in the portfolio, the greater the benefits of optimizing returns and/or reducing risk. By increasing the number of constituents into the portfolio, it is expected that there will be a risk reduction benefit to a point where these benefits begin to decrease. Husnan (2005) explains that in order to minimize investment risk, investors can diversify by combining various constituents in their investment, in other words, they form a portfolio. Tandelilin (2001) recommends that the number of constituents that can minimize portfolio risk is around 15 constituents. Alteza (2010) also explains that the benefits of reducing portfolio risk will reach its peak when the portfolio consists of several certain constituents, and after that the benefits of risk reduction will not have a significant effect. The portfolio carried out at the lowest point of portfolio risk is an efficient portfolio. On the other hand, Majid and Kassim (2010) stated that the very fast growth in the Islamic capital market has triggered a lot of attention to understand the value of integration of various countries that offer Islamic stock indexes in the interest of building a global Islamic stock portfolio. Although there is a high integration value between countries, it is still possible to diversify because each country still has various geopolitical and economic conditions with their respective advantages and disadvantages especially related to the COVID-19 crisis (Harjoto \& Rossi, 2021; Rakshit \& Neog, 2021). Although market in general reacts negatively to the COVID-19 reported cases (Jamaani, 2021), Islamic finance has been empirically shown to have better performance during this crisis (Akkas \& Al Samman, 2021; Sugiharto et al., 2021). However, investors are still required to build their investment portfolio beyond halal issues and consideration. Once investment destination countries are identified in this research, it is indispensable for the investors to analyse and select the promising sectors and equities as they also behave diversely during this crisis (Min et al., 2021).

\section{Research Methods}

Unlike other research in Islamic equity which are predominantly comparing Islamic market with the conventional counterparts (e.g. Al-Khazali et al., 2014; Al-Yahyaee et al., 2020; Albaity \& Ahmad, 2008; Ho et al., 2014), this research aimed to compare the risk and return of different country-based Islamic indices in order to formulate the optimum global portfolio. Countries that were employed as constituents in the simulation of global portfolio in this research formation were countries that have an Islamic composite index, while regional indexes such as the GCC (Gulf Cooperation Council) Islamic index for the gulf countries and the Asia Pacific Islamic index were not included. There are 12 countries that have a country Islamic composite index and thus were considered as the constituents. The data used were the historical monthly closing figures for each country index during the first year of the COVID-19 turbulence throughout 2020 which could be accessed openly through the financial data provider such as Yahoo Finance, Investing.com, Google Finance, and Bloomberg.

Data analysis was performed using the Single Index Model in order to form an optimal portfolio, by applying it to Microsoft Excel-based formulas. The Single Index Model is also often referred to as the Sharpe Model as it was developed by William Sharpe in 1963 (Sulistiani et al., 2017). The first step was done by calculating the expected return and the risk level of each constituent by first calculating the realized return $\left(\mathrm{E}\left(\mathrm{R}_{\mathrm{i}}\right)\right)$.

$E\left(R_{i}\right)=\frac{\Sigma R_{i}}{n}$ 
Measurement of risk was performed by calculating the standard deviation $\left(\sigma_{\mathrm{i}}\right)$ that reflects the possibility of the deviation of realized return from the expected return. Standard deviation is the square root of the variance of realized returns $\left(\sigma_{\mathrm{i}}^{2}\right)$.

$\sigma_{i}=\sqrt{\sigma_{i}^{2}}$

$\sigma_{i}^{2}=\frac{1}{n-1} \cdot \sum_{t-1}^{n}\left(R_{i t}-E\left(R_{i}\right)\right)^{2}$

A standard is needed as a criterion to determine which countries are eligible to become part of the optimal global Islamic stock portfolio. In a Single Index Model, Excess Return to Beta (ERB) is the main determinant of eligibility. ERB is defined as the difference between expected returns and risk-free returns $\left(\mathrm{R}_{\mathrm{f}}\right)$, which in this study the historical data of Fed-Rate was used.

$E R B_{i}=\frac{E\left(R_{i}\right)-R_{f}}{\beta_{i}}$

An optimal global portfolio will contain country indices that have high ERB values, an index with a low ERB value are not included in an optimal portfolio (Jogiyanto, 2010), thus a CutOff Point is required to determine the limit of ERB value.

$C=\frac{\sigma_{m}^{2} \cdot \Sigma_{j=1}^{1}\left(\frac{\beta_{i}\left(E\left(R_{i}\right)-R_{f}\right)}{\sigma_{e i}^{2}}\right)}{1+\sigma_{m}^{2} \cdot \Sigma_{j=1}^{1}\left(\frac{\beta_{i}^{2}}{\sigma_{e i}^{2}}\right)}$

Constituents whose ERB value exceeded the Cut-Off Point were then determined for the optimal proportion of funds $\left(\mathrm{W}_{\mathrm{i}}\right)$, by first determining the optimization scale for each constituent portfolio $\left(\mathrm{Z}_{\mathrm{i}}\right)$.

$W_{i}=\frac{Z_{i}}{\sum_{j=1}^{n} z_{j}}$

$Z_{i}=\frac{\beta_{i}}{\sigma_{e i}{ }^{2}}\left(\left(\frac{E\left(R_{i}\right)-R_{f}}{\beta_{i}}\right)-C\right)$

The next stage was to analyse the portfolio that has been formed with the optimal proportion of each constituent. In this analysis, the level of return and risk of all constituents individually was required first. Portfolio return $\left(E\left(R_{\mathrm{p}}\right)\right)$ is the sum of the average return of all constituents individually by considering the weight of each constituent.

$E\left(R_{p}\right)=\sum_{i=1}^{n}\left(W_{i} \cdot E\left(R_{i}\right)\right)$

How to determine portfolio risk $\left(\sigma_{\mathrm{p}}{ }^{2}\right)$ is not the same as determining portfolio return which is the sum of the average return of all individual constituents. Portfolio risk can be even less than the average individual risk.

$\sigma_{p}^{2}=\left(\sum_{i=1}^{n} W_{i} \cdot \beta_{i}\right)^{2} \cdot \sigma_{m}^{2}+\left(\sum_{i=1}^{n} W_{i} \cdot \sigma_{e i}{ }^{2}\right)^{2}$

In order to compare portfolio performance with market performance, a coefficient of variation is required. Information regarding the coefficient of variation can be useful for investors to provide an overview of the relative risk to return.

$v_{p}=\frac{\sigma_{p}}{E\left(R_{p}\right)}$

The following diagram illustrates the data processing flow as well as the relationship between variables in this study. 


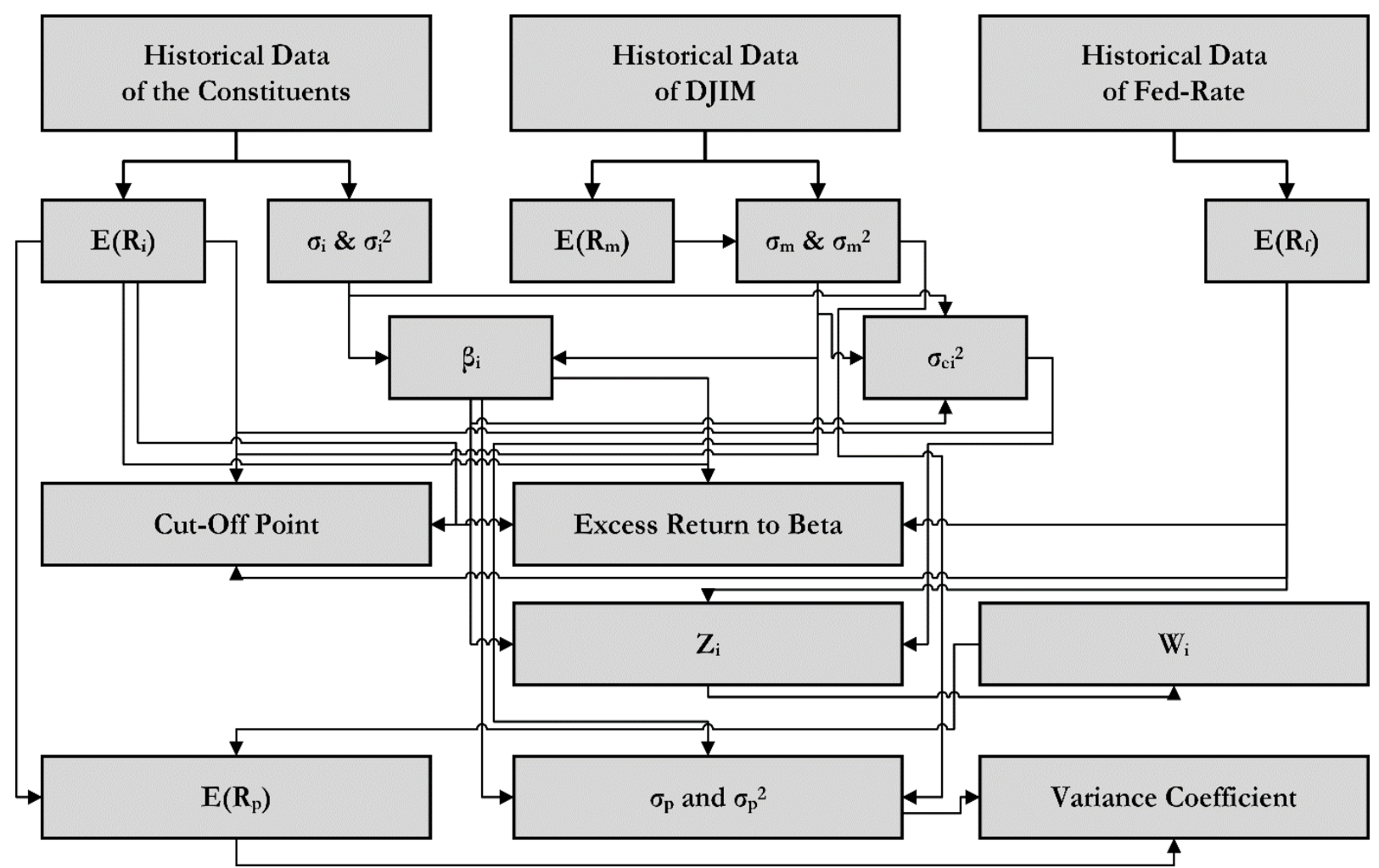

Source: Prepared by the authors

Figure 2. Operationalization of Variables

\section{Results and Discussion}

\section{Expected Return $\left(\mathbf{E}\left(\mathbf{R}_{\mathrm{i}}\right)\right)$ and Risk $\left(\sigma_{\mathrm{i}}\right)$}

A calculation to find expected returns and risks was carried out using a historical approach by taking into account changes in the closing price per month that occurred in the past. In this study, the closing figures per month of each constituent country during the pandemic in 2020 were used. The following is a table that shows the expected return and risk of the Islamic stock index in the constituent countries of this study:

Table 1. Return and risk of each constituent during 2020

\begin{tabular}{clccc}
\hline No. & Constituent Countries & $\mathrm{E}\left(\mathrm{R}_{\mathrm{i}}\right)$ & $\sigma_{\mathrm{i}}^{2}$ & $\sigma_{\mathrm{i}}$ \\
\hline 1 & Canada & 0.0255364 & 0.0116215 & 0.1078033 \\
2 & China & 0.0245728 & 0.0032312 & 0.0568437 \\
3 & India & 0.0269930 & 0.0058499 & 0.0764846 \\
4 & Indonesia & 0.0049329 & 0.0057156 & 0.0756017 \\
5 & Japan & 0.0259449 & 0.0039866 & 0.0631393 \\
6 & Kuwait & 0.0004626 & 0.0073095 & 0.0854955 \\
7 & Malaysia & 0.0136894 & 0.0040096 & 0.0633213 \\
8 & Sri Lanka & 0.0103847 & 0.0087652 & 0.0936228 \\
9 & Turkey & 0.0339355 & 0.0042097 & 0.0648823 \\
10 & United Arab Emirates & 0.0029677 & 0.0119005 & 0.1090893 \\
11 & United Kingdom & 0.0062071 & 0.0065334 & 0.0808295 \\
12 & United States & 0.0250039 & 0.0060773 & 0.0779572 \\
\hline
\end{tabular}

Source: Prepared by the authors

From the table above, it can be seen that all constituent countries have a positive expected return value, this means that at this stage, all countries were eligible as investment options because only countries with positive expected returns deserve to be chosen and proceeded to the next stages. The country that showed the greatest return was Turkey with an average monthly return of 
0.0339355 or $3.39 \%$. The second-highest yielding country was India with an average monthly yield of $2.69 \%$. Meanwhile, the countries with the greatest risk were the United Arab Emirates and Canada, with a standard deviation of $10.9 \%$ and $10.7 \%$, respectively, the rest of the countries had a risk of less than $10 \%$.

\section{Beta $(\beta)$ and Residual Error Variants $\left(\sigma_{\mathrm{ei}}{ }^{2}\right)$}

Single Index Model requires beta $(\beta)$ of each constituent which describes the volatility of returns per country to market return (DJIM). Beta coefficients can be positive or negative. If the beta is positive, then an increase in market returns will cause an increase in constituent returns. Meanwhile, if the beta is negative, then an increase in market return will cause a decrease in constituent returns. The size of the normal beta coefficient is $\beta=1$. If $\beta<1$, it is called a defensive constituent, which means that if there is an increase in market return of $\mathrm{x} \%$, then the constituent's return will increase by less than $\mathrm{x} \%$ and vice versa. If $\beta>1$, it is called aggressive constituent, which means that if the market return increases by $\mathrm{x} \%$ then the constituent's return will increase by more than $\mathrm{x} \%$ and vice versa. When the beta value is greater, the greater the influence of the market rate of return, so the higher the risk inherent in the constituent.

Table 2. Beta $(\beta)$ and Residual Error Variants $\left(\sigma_{\mathrm{ei}}^{2}\right)$ of each constituent during 2020

\begin{tabular}{clccc}
\hline No. & Constituent Countries & Covariant & $\beta$ & $\sigma_{\mathrm{ei}}{ }^{2}$ \\
\hline 1 & Canada & 0.0065093 & 2.0145094 & -0.0093278 \\
2 & China & 0.0028798 & 0.5578587 & 0.0016247 \\
3 & India & 0.0039741 & 0.7698551 & 0.0027904 \\
4 & Indonesia & 0.0041747 & 0.8087093 & 0.0023395 \\
5 & Japan & 0.0032239 & 0.6245241 & 0.0019732 \\
6 & Kuwait & 0.0037029 & 0.7173130 & 0.0046534 \\
7 & Malaysia & 0.0030783 & 0.5963180 & 0.0021739 \\
8 & Sri Lanka & 0.0040526 & 0.7850542 & 0.0055837 \\
9 & Turkey & 0.0031674 & 0.6135894 & 0.0022662 \\
10 & United Arab Emirates & 0.0057421 & 1.1123463 & 0.0055133 \\
11 & United Kingdom & 0.0051692 & 1.0013656 & 0.0013571 \\
12 & United States & 0.0050720 & 0.9825321 & 0.0010939 \\
\hline
\end{tabular}

Source: Prepared by the authors

Based on the calculation results, all constituents have a positive beta $(\beta)$, which means that an increase in market return (DJIM) would lead to an increase in returns in all constituent countries. There were three countries that were aggressive, namely Canada, the United Arab Emirates, and the United Kingdom, while the rest were defensive with a beta coefficient of less than one $(\beta<1)$ except for the United States with its beta value close to 1. China, Malaysia, Turkey, and Japan were the most defensive countries. Meanwhile, the country with variance levels of residual errors that represent the lowest unsystematic risk was Canada, while the highest was Sri Lanka.

\section{Excess Return to Beta (ERB) and Cut-Off Point}

In selecting the constituents to be included in an optimal Islamic global portfolio, certain criteria are needed. All constituents were arranged into a ranking based on Excess Return to Beta (ERB) from highest to lowest. Only country-based Islamic indices that have positive ERB values and are greater than the Cut-Off Point have the opportunity to be the candidates that will form an optimal Islamic global portfolio, while countries that have a negative ERB value and less than the Cut-Off Point will not be included in the optimal portfolio formation.

From the calculations carried out, all countries had positive ERB values, however, there were three countries that have ERB values smaller than the Cut-Off Point. These countries were the United Kingdom, United Arab Emirates, and Canada. Therefore, these three countries needed to be eliminated from the list of candidates for optimal portfolio formation. It explains that the returns of these countries were not worth the risk. 
Table 3. Excess Return to Beta (ERB) and Cut-Off Point Comparison

\begin{tabular}{|c|c|c|c|c|c|}
\hline Rank & Constituent Countries & ERB & & Cut-Off Point & Result \\
\hline 1 & China & 0.317217 & $>$ & \multirow{12}{*}{0.1610320} & Pass \\
\hline 2 & Turkey & 0.303664 & $>$ & & Pass \\
\hline 3 & Japan & 0.285553 & $>$ & & Pass \\
\hline 4 & Malaysia & 0.278507 & $>$ & & Pass \\
\hline 5 & India & 0.233008 & $>$ & & Pass \\
\hline 6 & Kuwait & 0.213090 & $>$ & & Pass \\
\hline 7 & Sri Lanka & 0.207342 & $>$ & & Pass \\
\hline 8 & Indonesia & 0.194535 & $>$ & & Pass \\
\hline 9 & United States & 0.180547 & $>$ & & Pass \\
\hline 10 & United Kingdom & 0.158380 & $<$ & & Eliminated \\
\hline 11 & Unite Arab Emirates & 0.139666 & $<$ & & Eliminated \\
\hline 12 & Canada & 0.088322 & $<$ & & Eliminated \\
\hline
\end{tabular}

Source: Prepared by the authors

\section{Proportion of Investment Funds $\left(\mathrm{W}_{\mathrm{i}}\right)$}

After obtaining the nine selected countries to enter into the optimal portfolio formation, it could now be calculated how much portion of the funds (Wi) that should be placed in each constituent country that passed by first determining the weighted scale $(\mathrm{Zi})$.

Table 4. Result of Weighted Scale (Zi) and Proportion (Wi) Calculation

\begin{tabular}{clcc}
\hline Rank & Constituent Countries & $\mathrm{Z}_{\mathrm{i}}$ & $\mathrm{W}_{\mathrm{i}}$ \\
\hline 1 & China & 53.6280 & $23.5845 \%$ \\
2 & Japan & 39.4120 & $17.3326 \%$ \\
3 & Turkey & 38.6189 & $16.9838 \%$ \\
4 & Malaysia & 32.2240 & $14.1715 \%$ \\
5 & India & 19.8580 & $8.7332 \%$ \\
6 & United States & 17.5283 & $7.7086 \%$ \\
7 & Indonesia & 11.5814 & $5.0933 \%$ \\
8 & Kuwait & 8.0248 & $3.5291 \%$ \\
9 & Sri Lanka & 6.5110 & $2.8634 \%$ \\
\hline & & & $100 \%$ \\
\hline
\end{tabular}

Source: Prepared by the authors

Based on the results of the above calculations, it can be seen that the largest portion of funds is expected to be placed in China, which is $23.58 \%$ of the total investment funds that can be allocated by investors for their global portfolio of Islamic stocks, while the next largest portions are expected to be allocated in Japan, Turkey, and Malaysia with a portion of $17.33 \%, 16.98 \%$, and $14.17 \%$ respectively. The smallest fund will be in Sri Lanka at $2.86 \%$.

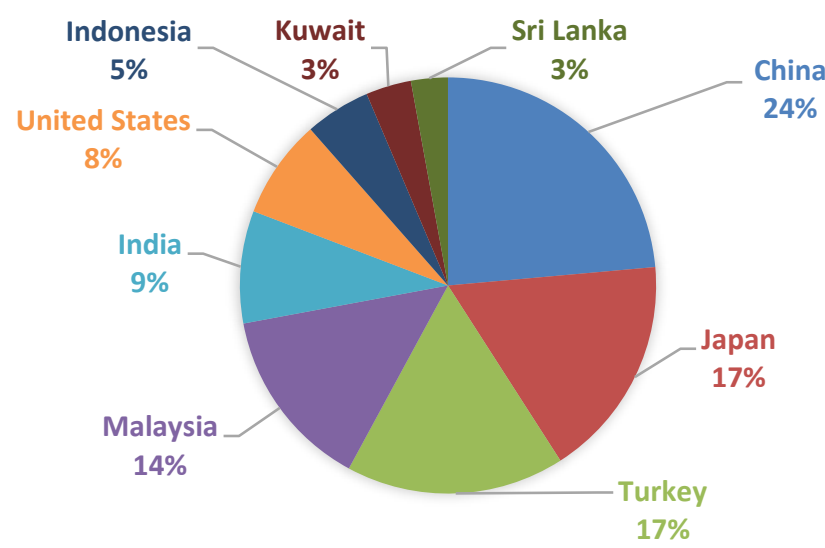

Source: Prepared by the authors

Figure 3. Optimal Proportion Calculation Results 
It is interesting to find that China, as the first country affected by the COVID-19, receives the largest prospective proportion of Islamic global asset allocation as its beta $(\beta)$ shows that this country was the most defensive country to the global systematic market risk and turbulence particularly during the first year of the COVID-19 period. This confirms that while global conditions were experiencing a worsening trend related to the turbulence of COVID-19, China was actually experiencing the opposite, which was a recovery trend. This provides a good opportunity for multinational Islamic investors to diversify their investments by considering China as their number one investment destinations besides Japan, Turkey, and Malaysia which are also promising countries.

\section{Expected Return of the Portfolio $\left(\mathrm{E}\left(\mathrm{R}_{\mathrm{p}}\right)\right)$}

Investors need to know how much the expected return of the portfolio that has been formed to be compared with the market expected returns that have been previously known. The following is a table that shows the calculation of the expected return of the generated portfolio by multiplying the average expected return with the weight of each constituent:

Table 5. Calculation Result of Portfolio Expected Return $\left(\mathrm{E}\left(\mathrm{R}_{\mathrm{p}}\right)\right)$

\begin{tabular}{llc}
\hline No. & Constituent Countries & $\mathrm{W}_{\mathrm{i}} * \mathrm{E}\left(\mathrm{R}_{\mathrm{i}}\right)$ \\
\hline 1 & China & 0.005795 \\
2 & Japan & 0.004497 \\
3 & Turkey & 0.005764 \\
4 & Malaysia & 0.001940 \\
5 & India & 0.002357 \\
6 & United States & 0.001927 \\
7 & Indonesia & 0.000251 \\
8 & Kuwait & 0.000016 \\
9 & Sri Lanka & 0.000297 \\
\hline & & Total $\left(\mathrm{E}\left(\mathrm{R}_{\mathrm{p}}\right)\right)$ \\
\hline
\end{tabular}

Source: Prepared by the authors

It can be seen in the calculation results table above that the portfolio that has been formed provide expected returns of 0.022846 or $2.285 \%$ every month. This return is a promising return because it is greater than the global market expected return (Dow Jones Industrial Average) of $1.035 \%$ per month, using historical data throughout 2020 . This shows that through the formation of this portfolio, returns could be optimized.

\section{Risk of the Portfolio $\left(\sigma_{\mathrm{p}}\right)$}

The following table shows the calculation of portfolio risk involving the proportion $\left(\mathrm{W}_{\mathrm{i}}\right)$, beta $\left(\beta_{\mathrm{i}}\right)$, and residual error variance $\left(\sigma_{\mathrm{ei}}{ }^{2}\right)$ :

Table 6. Calculation Result of the Risk of Portfolio

\begin{tabular}{llcc}
\hline No. & Constituent Countries & $\mathrm{W}_{\mathrm{i}} * \beta_{\mathrm{i}}$ & $\left(\mathrm{W}_{\mathrm{i}} * \sigma_{\mathrm{e}}{ }^{2}\right)^{2}$ \\
\hline 1 & China & 0.1315684 & 0.000000146826 \\
2 & Japan & 0.1082463 & 0.000000116965 \\
3 & Turkey & 0.1042109 & 0.000000148138 \\
4 & Malaysia & 0.0845069 & 0.000000094913 \\
5 & United States & 0.0757395 & 0.000000007111 \\
6 & India & 0.0672327 & 0.000000059385 \\
7 & Indonesia & 0.0411898 & 0.000000014199 \\
8 & Kuwait & 0.0253150 & 0.000000026969 \\
9 & Sri Lanka & 0.0224794 & 0.000000025563 \\
\hline & Total & 0.6604888 & 0.000000640068 \\
\hline & $\sigma_{\mathrm{p}}{ }^{2}$ & & 0.0022520 \\
& $\sigma_{\mathrm{p}}$ & & 0.0474549 \\
\hline
\end{tabular}

Source: Prepared by the authors 
From the table of calculation results above, it can be seen that the portfolio variance $\left(\sigma_{\mathrm{p}}{ }^{2}\right)$ is 0.0022520 , while the risk $\left(\sigma_{\mathrm{p}}\right)$ which is the square root of the variance is 0.0474549 . This risk is much smaller than the global market risk (Dow Jones Industrial Average) of 0.0814043 or even the global Islamic market (DJIM) of 0.0718482 .

\section{Comparison of Portfolio Coefficient of Variance $\left(v_{p}\right)$ with Market Coefficient of Variance $\left(\mathrm{v}_{\mathrm{m}}\right)$}

The coefficient of variation can provide information to investors to compare several investment alternatives, then determine the option that provides the optimal return possibility in accordance with the amount of risk contained in the investment. Information regarding the coefficient of variation can be useful for investors to provide an overview of risk relative to stock returns. The following is a comparison of the coefficient of variance of DJIM (Islamic Global Market) and DJIA (Global Market) with the coefficient of variance of the generated portfolio $\left(\mathrm{v}_{\mathrm{p}}\right)$ :

Table 7. Comparison of Portfolio Coefficient of Variance $\left(\mathrm{v}_{\mathrm{p}}\right)$

\begin{tabular}{ccccc}
\hline $\mathrm{v}_{\mathrm{p}}$ & & $\mathrm{v}_{\mathrm{m} \text { (global Islamic) }}$ & & $\mathrm{v}_{\mathrm{m} \text { (global unrestricted) }}$ \\
\hline 2.07720666 & $<$ & 2.97062568 & $<$ & 7.86212541 \\
\hline
\end{tabular}

Source: Prepared by the authors

From the table above, it can be seen that the relative risk of the established portfolio is much smaller than the relative market risk. The portfolio that has been formed has a relative coefficient of 2.07720666 , only $69.92 \%$ of the relative risk of the Islamic market which has a value of 2.97062568 and $26.42 \%$ of the relative risk of the conventional market of 7.86212541 . Besides, this research also finds that even the undiversified Islamic global equity market performed better than the unrestricted conventional counterpart during the first year of the COVID-19 crisis.

\section{Conclusion}

This study emanated the map of the global Islamic equity markets by building a global Islamic stock portfolio with optimal returns and minimal risk, this was conducted by processing and analysing the performance of countries providing Islamic stock indexes during the COVID-19 crisis, with recommended $23.58 \%$ asset allocation in China; $17.33 \%$ in Japan; $16.98 \%$ in Turkey; $14.17 \%$ in Malaysia; $8.73 \%$ in India; $7.70 \%$ in the US; $5.09 \%$ in Indonesia; $3.52 \%$ in Kuwait; and $2.86 \%$ in Sri Lanka. With an expected return of $2.28 \%$ monthly, this portfolio return is also promising as it is greater than the expected global market return (Dow Jones Industrial Average) of only 1.03\% per month. The calculated portfolio risk is $4.75 \%$, it is much smaller than the market risk of $8.14 \%$. Three countries were eliminated as their Excess Return to Beta were lower than the Cut-Off Point, these countries were the United Kingdom, United Arab Emirates, and Canada, it means that the returns of these countries were not worth the risk.

It is interesting to find that China as the first country suffering from the COVID-19 gets the largest prospective proportion of Islamic global asset allocation as its beta $(\beta)$ shows that this country was the most defensive country to the global systematic market risk and turbulence during the first year of COVID-19 period. This also exposes that in this period China was experiencing a quite different trend when compared to the global COVID-19 condition. Further research can be conducted to investigate and explore the fundamental reasons why China excels in this regard. Other promising countries during the crisis are Japan, Turkey, and Malaysia. For investors, this research provides recommendations regarding which countries are suitable for future diversification of global Islamic stock investment destinations by considering the returns and risks of each country during the COVID-19 crisis. By following the recommendations generated from this research, multinational Islamic investors can obtain optimum returns with minimum risk while facing COVID-19 turbulence. 


\section{References}

Abbes, M. B., \& Trichilli, Y. (2015). Islamic stock markets and potential diversification benefits. Borsa Istanbul Review, 15(2), 93-105. https://doi.org/10.1016/j.bir.2015.03.001

Ahmed, H. (2003). Defining ethics in Islamic finance: looking beyond legality. 8th International Conference on Islamic Economics and Finance, 2003, 1-10. Retrieved from http://www.iefpedia.com/english/wp-content/uploads/2011/12/Habib-Ahmed.pdf

Akkas, E., \& Al Samman, H. (2021). Are Islamic financial institutions more resilient against the COVID-19 pandemic in the GCC countries? International Journal of Islamic and Middle Eastern Finance and Management. https://doi.org/10.1108/imefm-07-2020-0378

Al-Khazali, O., Lean, H. H., \& Samet, A. (2014). Do Islamic stock indexes outperform conventional stock indexes? A stochastic dominance approach. Pacific-Basin Finance Journal, 28, 29-46. https://doi.org/10.1016/j.pacfin.2013.09.003

Al-Yahyaee, K. H., Mensi, W., Rehman, M. U., Vo, X. V., \& Kang, S. H. (2020). Do Islamic stocks outperform conventional stock sectors during normal and crisis periods? Extreme comovements and portfolio management analysis. Pacific Basin Finance Journal, 62, 101385. https://doi.org/10.1016/j.pacfin.2020.101385

Albaity, M., \& Ahmad, R. (2008). Performance of Syariah and composite indices: Evidence from bursa Malaysia. Asian Academy of Management Journal of Accounting and Finance, 4(1), 23-43. Retrieved from http://web.usm.my/journal/aamjaf/vol\%204-1-2008/4-1-2.pdf

Ali, S. S. (2007). Islamic capital markets products, regulations and development. Islamic Research \& Training Institute, Islamic Development Bank. Retrieved from http://www.iefpedia.com/english/wpcontent/uploads/2009/10/Islamic-Capital-Markets-Products-Regulation-andDevelopment-by-Salman-Syed-Ali.pdf

Alteza, M. (2010). Diktat manajemen investasi, Universitas Negeri Yogyakarta. Retrieved from http://staffnew.uny.ac.id/upload/132303686/pendidikan/Diktat\%20Manajemen\%20Inv estasi.pdf

Ashraf, D. (2013). Performance evaluation of Islamic mutual funds relative to conventional funds: Empirical evidence from Saudi Arabia. International Journal of Islamic and Middle Eastern Finance and Management, 6(2), 105-121. https://doi.org/10.1108/17538391311329815

Ashraf, D., \& Mohammad, N. (2014). Matching perception with the reality-performance of Islamic equity investments. Pacific Basin Finance Journal, 28, 175-189. https://doi.org/10.1016/j.pacfin.2013.12.005

Askari, H., Iqbal, Z., Krichene, N., \& Mirakhor, A. (2010). The stability of Islamic finance: creating a resilient financial environment for a secure future. John Wiley \& Sons.

Balcilar, M., Demirer, R., \& Hammoudeh, S. (2015). Global risk exposures and industry diversification with Shariah-compliant equity sectors. Pacific-Basin Finance Journal, 35, 499520. https://doi.org/10.1016/j.pacfin.2015.09.002

Binmahfouz, S. S. (2012). Investment characteristics of Islamic investment portfolios: Evidence from Saudi mutual funds and global indices [Durham University]. In Durbam Theses, Durham University. Retrieved from http://etheses.dur.ac.uk/4440/

Bodie, Z., Kane, A., \& Marcus, A. J. (2006). Investasi, Salemba Empat.

Chapra, M. U. (2011). The global financial crisis: Some suggestions for reform of the global financial architecture in the light of Islamic finance. Thunderbird International Business Review, 53(5), 565-579.doi:10.1002/tie.20435

Cherif, M., \& Gammoudi, M. (2011). Impact of the U.S. subprime crises on MENA stock markets: new empirical investigation. La Revue Du Financier, 120-128. Retrieved from 
https://larevuedufinancier.fr/pdf/extrait/198-7.pdf

Derigs, U., \& Marzban, S. (2008). Review and analysis of current shariah-compliant equity screening practices. International Journal of Islamic and Middle Eastern Finance and Management, 1(4), 285-303. https://doi.org/10.1108/17538390810919600

Dewandaru, G., Rizvi, S. A. R., Bacha, O. I., \& Masih, M. (2014). What factors explain stock market retardation in Islamic countries. Emerging Markets Review, 19, 106-127. https://doi.org/10.1016/j.ememar.2014.04.006

Enisan, A. A., \& Olufisayo, A. O. (2009). Stock market development and economic growth: Evidence from seven sub-Sahara African countries. Journal of Economics and Business, 61(2), 162-171. https://doi.org/10.1016/j.jeconbus.2008.05.001

Faye, I., Triki, T., \& Kangoye, T. (2013). The Islamic finance promises: Evidence from Africa. Review of Development Finance, 3(3), 136-151. https://doi.org/10.1016/j.rdf.2013.08.003

Fethi, M. D., Matallín, J. C., \& Tortosa-Ausina, E. (2014). On the comparative performance of socially responsible and Islamic mutual funds. Journal of Economic Behavior \& Organization, 103, S108-S128. https://doi.org/10.1016/j.jebo.2013.06.011

Fitriany. (2012). Analisa pengaruh krisis global financial terhadap Jakarta Islamic index (JII) dan index harga saham gabungan (IHSG). Jurnal Ekonomi dan Kenangan Islam, 2(1), 1-12. Retrieved from https://journal.uii.ac.id/JEKI/article/view/8764

Hakim, S., \& Rashidian, M. (2002). Risk \& return of Islamic stock market indexes. 9th Economic Research Forum Annual Meetings Sharjah UAE, 2, 26-28. Retrieved from http://www.iefpedia.com/english/wp-content/uploads/2009/09/Risk-Return-ofIslamic-Stock-Market-Indexes.pdf

Hambali, S. N., Jamal, J., Mohd Ali, H., \& Abdul Manap, N. (2010). Shari'ah compliant issues in the Islamic capital market and shari ah screening in Malaysia. International Research Symposium in Service Management, August 2010, 24-27. Retrieved from https://silo.tips/download/syariah-compliant-issues-in-the-islamic-capital-market-and-shari-ah-screening-i

Harjoto, M. A., \& Rossi, F. (2021). Market reaction to the COVID-19 pandemic: evidence from emerging markets. International Journal of Emerging Markets. https://doi.org/10.1108/IJOEM-05-2020-0545

Hearn, B., Piesse, J., \& Strange, R. (2011). The role of the stock market in the provision of Islamic development finance: Evidence from Sudan. Emerging Markets Review, 12(4), 338-353. https://doi.org/10.1016/j.ememar.2011.04.004

Ho, C. S. F., Abd Rahman, N. A., Yusuf, N. H. M., \& Zamzamin, Z. (2014). Performance of global Islamic versus conventional share indices: International evidence. Pacific-Basin Finance Journal, 28, 110-121. https://doi.org/10.1016/j.pacfin.2013.09.002

Husnan, S. (2005). Dasar-dasar teori portofolio dan analisis sekuritas. UPP STIM YKPN.

Iqbal, Z., \& Mirakhor, A. (2013). Islamic capital markets and development. Economic Development and Islamic Finance, The World Bank. https://doi.org/10.1596/978-0-8213-9953-8

Jamaani, F. (2021). The single and joint effects of financial intervention policies introduced by governments and power distance culture on returns of equity markets during the COVID19. Cross Cultural and Strategic Management. https://doi.org/10.1108/CCSM-02-2021-0022

Jawadi, F., Jawadi, N., \& Louhichi, W. (2014). Conventional and Islamic stock price performance: An empirical investigation. International Economics, 137, 73-87. https://doi.org/10.1016/j.inteco.2013.11.002

Jogiyanto. (2010). Teori portofolio dan analisis investasi (Edisi 7). BPFE.

Kassim, S. (2016). Islamic finance and economic growth: The Malaysian experience. Global Finance 
Journal, 30, 66-76. https://doi.org/10.1016/j.gfj.2015.11.007

Khatkhatay, M. H., \& and Nisar, S. (2007). Shariah compliant equity investments: An assessment of current screening norms. Islamic Economic Studies, 15(1), 47-76. Retrieved from http://www.irti.org/English/Research/Documents/IES/085.pdf

Maharani, N. K. (2017). Analisis perbandingan kinerja saham Syariah antara DJIMI, FTSE GIIS. KLSESI, dan JII. Jurnal Ekonomi dan Keuangan Islam, 3(1), 10-18. https://doi.org/10.20885/JEKI.vol3.iss1.art2

Mahfooz, S. bin, \& Ahmed, H. (2014). Shariah investment screening criteria: A critical review. Journal of King Abdulariz University, Islamic Economics, 27(1), 3-39. https://doi.org/10.4197/Islec.27-1.1

Majid, M. S. A., \& Kassim, S. H. (2010). Potential diversification benefits across global Islamic equity markets. Journal of Economics Cooperation and Development, 31(4), 103-126. Retrieved from https://jecd.sesric.org/pdf.php? file=ART10020401-2.pdf

Marzban, S., \& Asutay, M. (2012). The impact of asset-based versus market capitalization-based shari'ah screening on US and Japanese equities: An empirical analysis. Asian and African Area Studies, 11(2), 151-165. https://doi.org/10.1063/1.2756072

Min, H., Shin, S., \& Taltavull de La Paz, P. (2021). COVID-19 and the daily rate of return of three major industry sector stock price indices related to real estate. Journal of Property Investment and Finance. https://doi.org/10.1108/JPIF-02-2021-0015

Mohamad, S., Muhammad, M., Habib, F., \& Salim, K. (2015). Criteria for Determining The Shari'ah Compliance of Shares: A Fiqhi Analysis. ISR A International Journal of Islamic Finance, 7(2), 171. Retrieved from https://www.proquest.com/docview/1776417105?pqorigsite $=$ gscholar \& fromopenview $=$ true

Munawaroh, U., \& Sunarsih, S. (2020). The effects of Fama-French five factor and momentum factor on Islamic stock portfolio excess return listed in ISSI. Jurnal Ekonomi dan Kenangan Islam, 6(2), 119-133. https://doi.org/10.20885/jeki.vol6.iss2.art4

Najeeb, S. F., \& Vejzagic, M. (2013). Development, growth and challenges of islamic capital markets: comparative insights from the Malaysian, Indonesian, United Arab Emirates and Brunei Markets. Journal of Emerging Economies and Islamic Research, 1(3), 1-38. http://www.jeeir.com/index.php/jeeir/article/view/71

Narayan, P. K., \& Narayan, S. (2013). The short-run relationship between the financial system and economic growth: New evidence from regional panels. International Review of Financial Analysis, 29, 70-78. https://doi.org/10.1016/j.irfa.2013.03.012

Puspaningtyas, L. (2020, October 6). Kinerja saham BRI Syariah terjaga di masa pandemi, Republika. https://republika.co.id/berita/qhs9fo457/kinerja-saham-bri-syariah-terjaga-dimasa-pandemi

Rahman, A. A., Yahya, M. A., \& Nasir, M. H. M. (2010). Islamic norms for stock screening, a comparison between the Kuala Lumpur stock exchange Islamic index and the Dow Jones Islamic market index. International Journal of Islamic and Middle Eastern Finance and Management, 3(3), 228-240. http://dx.doi.org/10.1108/17538391011072426

Rakshit, B., \& Neog, Y. (2021). Effects of the COVID-19 pandemic on stock market returns and volatilities: evidence from selected emerging economies. Studies in Economics and Finance. https://doi.org/10.1108/SEF-09-2020-0389

Rethel, L., \& Abdalloh, I. (2015). Incultivating ethical behaviour in market transaction? The case of the Sharia online trading system in Indonesia. In G. Lovink, N. Tkacz, \& P. de Vries (Eds.), Moneylab Reader: An Intervention in Digital Economy (pp. 104-116). Institute of Network Cultures.

Retrieved from https://networkcultures.org/wp- 
content/uploads/2015/04/MoneyLab_reader.pdf

Rivai, V. (2010). Islamic Financial Management. Ghalia Indonesia.

Rizaldy, M. R., \& Ahmed, H. (2019). Islamic legal methodologies and Shariah screening standards: Application in the Indonesian stock market. Thunderbird International Business Review, 61(5), 793-805. https://doi.org/10.1002/tie.22042

Rizvi, S. A. R., Arshad, S., \& Alam, N. (2015). Crises and contagion in Asia Pacific - Islamic v/s conventional markets. Pacific-Basin Finance Journal, 34, 315-326. https://doi.org/10.1016/j.pacfin.2015.04.002

Rousseau, P. L., \& Wachtel, P. (2000). Equity markets and growth: Cross-country evidence on timing and outcomes, 1980-1995. Journal of Banking \& Finance, 24(12), 1933-1957. https://doi.org/10.1016/S0378-4266(99)00123-5

Saiti, B., Bacha, O. I., \& Masih, M. (2014). The diversification benefits from Islamic investment during the financial turmoil: The case for the US-based equity investors. Borsa Istanbul Review, 14(4), 196-211. https://doi.org/10.1016/j.bir.2014.08.002

Sugiharto, T., Azimkulovich, E. S., \& Misdiyono. (2021). Impact of the COVID-19 pandemic on the financial performance of Sharia commercial banks: An empirical evidence from Indonesia. IKONOMIKA: Jurnal Ekonomi dan Bisnis Islam, 6(1), 39-58. https://doi.org/10.24042/febi.v6i1.9014

Sulistiani, R. D., Topowijono, T., \& Wi Endang NP, M. G. (2017). Analisis pembentukan portofolio optimal saham berdasarkan metode model indeks tunggal. Jurnal Administrasi Bisnis, 51(2), 76-84.

Tandelilin, E. (2001). Analisis investasi dan manajemen portofolio. BPFE.

World Bank. (2020). Global economic prospects, Washington, DC: World Bank. https://openknowledge.worldbank.org/handle/10986/33748 License: CC BY 3.0 IGO. 